\title{
Kinetics and Mechanism of Palladium Catalysed Electron Transfer Reaction between Glutathione (Reduced) and Pyridinium Chlorochromate in Acid Medium
}

\author{
ALAKA DAS and P. MOHANTY* \\ P.G. Department of Chemistry, Utkal University, Vani Vihar, Bhubaneswar, 751004, India \\ gulualaka@gmail.com
}

Received 28 June 2012 / Accepted 8 July 2012

\begin{abstract}
The palladium $\left[\mathrm{Pd}^{+2}\right]$ catalysed electron transfer reaction between glutathione (reduced) $(\mathrm{GSH})$ and pyridinium chlorochromate $(\mathrm{PCC})$ has been studied spectrophotometrically over the range $2.00 \leq 10^{3}[\mathrm{GSH}] \leq 6.00,0.01 \leq\left[\mathrm{H}^{+}\right] \leq 0.03 \mathrm{~mol} \mathrm{dm}{ }^{-3}, 2.83 \leq 10^{5}\left[\mathrm{Pd}^{+2}\right] \leq 14.15$ and $20{ }^{0} \mathrm{C} \leq \mathrm{t} \leq 40{ }^{0} \mathrm{C}$. The rate of reaction was found to increase with the increase in $[\mathrm{GSH}]_{\mathrm{T}},\left[\mathrm{H}^{+}\right]_{\mathrm{T}}$ and $\left[\mathrm{Pd}^{+2}\right]$. The reaction was found to exhibit first order dependence in $[\mathrm{GSH}]_{\mathrm{T}},\left[\mathrm{H}^{+}\right]_{\mathrm{T}}$ and $\left[\mathrm{Pd}^{+2}\right]_{\mathrm{T}}$. The $\Delta \mathrm{H}^{f}(\mathrm{~kJ} / \mathrm{mol})$ and $\Delta \mathrm{S}^{\ddagger}\left(\mathrm{JK}^{-1} \mathrm{~mol}^{-1}\right)$ for the electron transfer reaction were found to be -27.7 and -243.9. The product of the reaction was found to be glutathione disulfide (GSSG) as indicated by infrared spectrum. The negative values of activation parameters favour the formation of the ordered transition state.
\end{abstract}

Keywords: Palladium, Glutathione (Reduced), Pyridinium chlorochromate and Electron transfer

\section{Introduction}

Glutathione, a tri peptide ( $\gamma L$-Glutanyl- $L$-cysteinylglycine) is a molecule that occurs in plants and animals (Figure 1). It is an antioxidant, preventing damage to important cellular components caused by reactive oxygen species such as free radical and peroxides ${ }^{1}$. The thiol group of glutathione reduces disulphide bonds formed within cycloplasmic protein to cysteines by serving as an electron donor. In the process glutathione is oxidized to its oxidized form glutathione disulphide (GSSG). Pyridinium chlorochromate (PCC) is a mild oxidizing agent. The electron transfer reactions of PCC with various molecules have been studied ${ }^{1-11}$. PCC is a mild oxidizing agent. The compound has been used extensively for the study of redox reactions of many biomolecules, but the electron transfer reaction of PCC with peptides GSH in presence of $\left[\mathrm{Pd}^{+2}\right]$ catalyst has not been studied. However the redox reactions of $[\mathrm{GSH}]$ with other oxidant have been studied ${ }^{12-15}$. The $\gamma L$-glutanyl- $L$-cysteinylglycine or GSH is the major low molecular mass thiol compound in plants and animals and its peptide $\gamma$-linkage is thought to protect it from degradation by aminopeptidases. It plays a role in signal transduction, gene expression, apoptosis, protein glutathionylation and NO metabolism. Palladium(II) is known to catalyse effectively several redox reactions. In order to understand the role of $\left[\mathrm{Pd}^{+2}\right]$ in the electron transfer reaction, the work has been undertaken. 
<smiles>NC(CCC(=O)NC(CS)C(=O)NCC(=O)O)C(=O)O</smiles>

Figure 1. Structure of glutathione

\section{Experimental}

Pyridinium chlorochromate has been synthesized by following the reported method ${ }^{16}$. The compound was characterized by estimating $\mathrm{Cr}(\mathrm{VI})$ iodometrically. The estimation of $\left[\mathrm{Pd}^{+2}\right]$ was carried out gravimetrically using dimethylglyoxime ${ }^{17}$. The acid strength of the medium was maintained by addition of $\mathrm{HClO}_{4}$. Kinetic measurements were recorded on a sytronic 119 PC scanning UV-Vis spectrophotometer (Figure 2). Reaction progress was monitored at $435 \mathrm{~nm}$. Pseudo first order condition were maintained though out the runs by using a large excess $(>5$ fold) of [GSH]. The constant $\left(\mathrm{k}_{\mathrm{obs}}\right)$ were obtained from the slope of $-\ln \left(A_{t}-A_{\infty}\right)$ versus ' $\mathrm{t}$ ' plots.

$$
-\ln \left(A_{\mathrm{t}}-A_{\infty}\right)=k_{\text {obs }} \mathrm{t}-\mathrm{C}
$$

Where $A_{t}$ and $A_{\infty}$ are the absorbances of the reaction mixture at time $t$ and at the completion of the reaction. The reported rate data represented as an average of duplicate runs were reproducible within $\pm 3 \%$ the correlation coefficient of the plots used determine $\mathrm{k}_{\text {obs }}$ were found to be 0.99 in most of the cases.

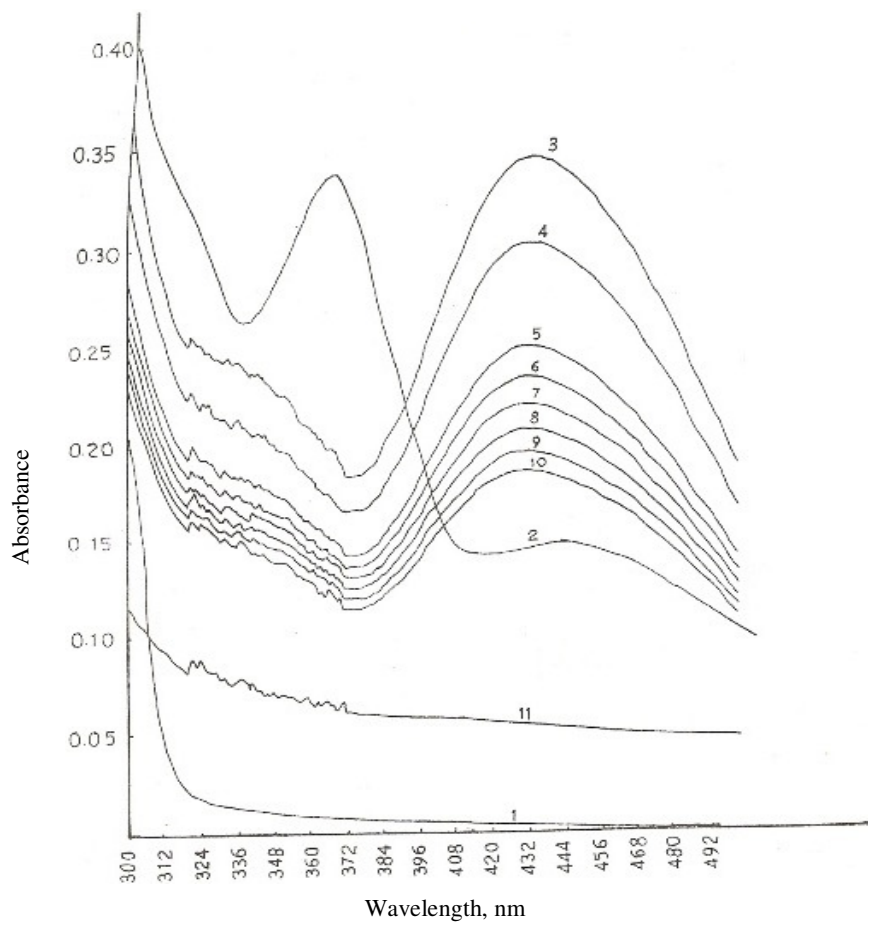

Figure 2. Repetitive spectral scan of PCC with GSH

(Curve 2: $[P C C]=4 \times 10^{-4} \mathrm{~mol} \mathrm{dm}^{-3}$, Curve 1: $[\mathrm{GSH}]=2 \times 10^{-3} \mathrm{~mol} \mathrm{dm}^{-3},\left[\mathrm{H}^{+}\right]=1.0 \times 10^{-2} \mathrm{~mol} \mathrm{dm}^{-3}, \mathrm{~T}$ $=30^{\circ} \mathrm{C}$, at different time intervals of $2 \mathrm{~min}$ (Curve 3-10), Curve 11 is after $24 \mathrm{H}$ ) 


\section{Results and Discussion}

The kinetic results obtained for the above reaction may be summarized as follows. With the varying concentration of $10^{3}[\mathrm{GSH}]_{\mathrm{T}}$ in the range 2.00 to $6.00 \mathrm{~mol} \mathrm{dm}^{-3}$, the $10^{4} \mathrm{k}_{\mathrm{obs}} \mathrm{sec}^{-1}$ $\left(25^{0} \mathrm{C}\right)$ increased from 6.03 to 11.35 when $\left[\mathrm{H}^{+}\right]=0.01 \mathrm{~mol} \mathrm{dm}^{-3},[\mathrm{PCC}]=4 \times 10^{-4} \mathrm{~mol} \mathrm{dm}^{-3}$ and $\left[\mathrm{Pd}^{+2}\right]=2.83 \times 10^{-5} \mathrm{~mol} \mathrm{dm}{ }^{-3}$ (Table 1). The $[\mathrm{GSH}]_{\mathrm{T}} /[\mathrm{PCC}]_{\mathrm{T}}$ was varied from 5.00 to 20.00. The $\mathrm{k}_{\mathrm{obs}}$ versus $[\mathrm{GSH}]_{\mathrm{T}}$ plot (Figure 3 ) was linear at all reported $\left[\mathrm{H}^{+}\right]_{\mathrm{T}}$ indicating $1^{\text {st }}$ order dependence of the reaction on $[\mathrm{GSH}]_{\mathrm{T}}$. At fixed $\left[\mathrm{Pd}^{+2}\right]$ and $\left[\mathrm{H}^{+}\right]$and $[\mathrm{GSH}]_{\mathrm{T}}$, the $\mathrm{k}_{\mathrm{obs}}$ does not change by changing $[\mathrm{PCC}]_{\mathrm{T}}$, hence the order of the reaction is one with respect to $[\mathrm{PCC}]_{\mathrm{T}}$. The rate law is therefore given by equation (1).

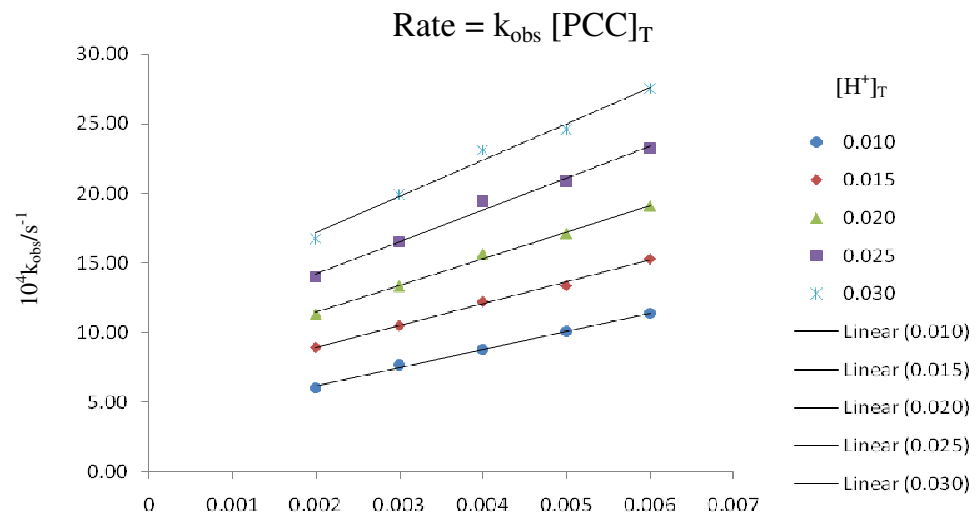

Figure 3. The plots of $10^{4} \mathrm{k}_{\mathrm{obs}}^{\mathrm{GSH}} / \mathrm{s}^{-1} \mathrm{~mol}^{-1} \mathrm{dm}^{3}$ versus $[\mathrm{GSH}]_{\mathrm{T}} / \mathrm{mol} \mathrm{dm}^{-3}$ at different $\left[\mathrm{H}^{+}\right]$ $\left(\left[\mathrm{PCC}_{T}=4.0 \times 10^{-4} \mathrm{~mol} \mathrm{dm} m^{-3}, t=25^{\circ} \mathrm{C},\left[\mathrm{H}^{+}\right]\right.\right.$was varied from 0.01 to $0.03 \mathrm{~mol} \mathrm{dm} m^{-3}$ and $[\mathrm{GSH}]$ was varied from 0.002 to $0.006 \mathrm{~mol} \mathrm{dm}^{-3}$ )

With $[\mathrm{PCC}]_{\mathrm{T}}=4 \times 10^{-4} \mathrm{~mol} \mathrm{dm}{ }^{-3}$ and $[\mathrm{GSH}]_{\mathrm{T}}=2 \times 10^{-3} \mathrm{~mol} \mathrm{dm}^{-3}, 10^{4} \mathrm{k}_{\mathrm{obs}}\left(25^{0} \mathrm{C}\right)$ changed from 6.03 to 16.77 as $\left[\mathrm{H}^{+}\right]_{\mathrm{T}}$ was changed from 0.01 to $0.03 \mathrm{~mol} \mathrm{dm}^{-3}$. This behavior was repeated for the entire $[\mathrm{GSH}]_{\mathrm{T}}$ range 0.002 to $0.006 \mathrm{~mol} \mathrm{dm}^{-3}$ (Figure 4). When $[\mathrm{PCC}]_{\mathrm{T}}=$ $4 \times 10^{-4},[\mathrm{GSH}]_{\mathrm{T}}=2 \times 10^{-3},\left[\mathrm{H}^{+}\right]_{\mathrm{T}}=0.01 \mathrm{~mol} \mathrm{dm}{ }^{-3}$, by changing $\left[\mathrm{Pd}^{+2}\right]_{\mathrm{T}}$ from $2.83 \times 10^{-5}$ to $14.15 \times 10^{-5} \mathrm{~mol} \mathrm{dm}^{-3}, 10^{4} \mathrm{k}_{\mathrm{obs}}\left(\mathrm{s}^{-1}\right)$ at $30^{0} \mathrm{C}$ changes from 7.13 to 39.83 (Figure 5).

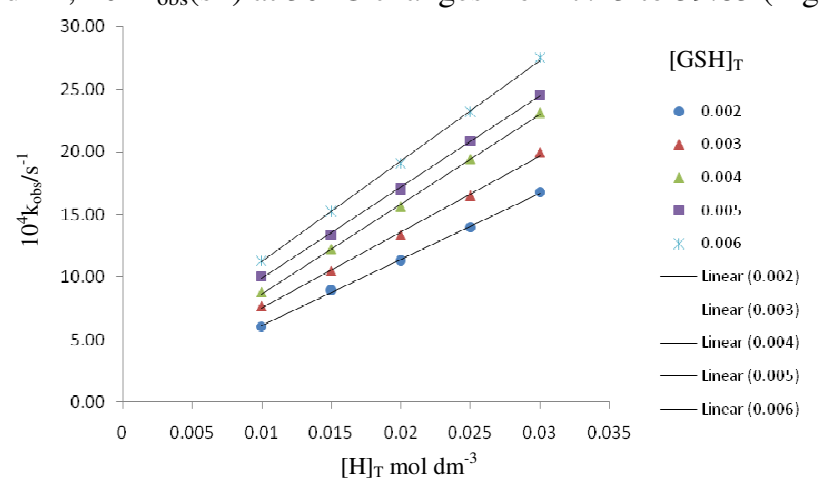

Figure 4. The plots of $10^{4} \mathrm{k}_{\mathrm{obs}} / \mathrm{s}^{-1}$ versus $\left[\mathrm{H}^{+}\right]_{\mathrm{T}} \mathrm{mol} \mathrm{dm}{ }^{-3}$ at different $\left[\mathrm{GSH}^{+}\right]_{\mathrm{T}}$ $\left([P C C]_{T}=4.0 \times 10^{-4} \mathrm{~mol} \mathrm{dm}^{-3}, t=25^{\circ} \mathrm{C} .\left[\mathrm{H}^{+}\right]\right.$was varied from 0.01 to $0.03 \mathrm{~mol} \mathrm{dm^{-3 }}$ and $[\mathrm{GSH}]$ was varied from 0.002 to $0.006 \mathrm{~mol} \mathrm{dm}^{-3}$ ) 


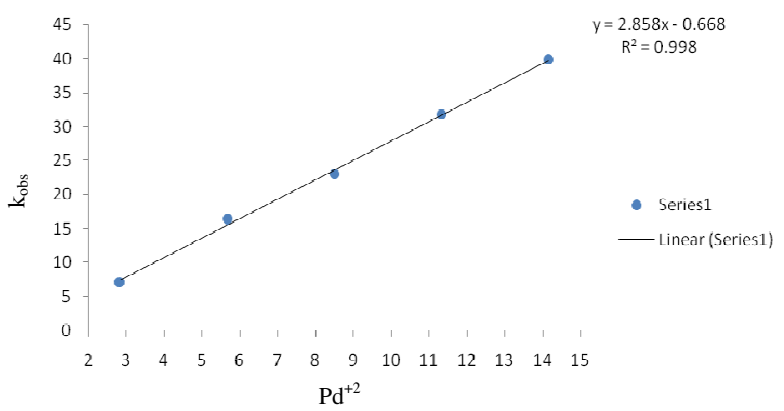

Figure 5. The plots of $10^{4} \mathrm{k}_{\mathrm{obs}} / \mathrm{s}^{-1}$ versus $\left[\mathrm{Pd}^{+2}\right]_{\mathrm{T}}$ mol dm ${ }^{-3}$ at different $\left[\mathrm{Pd}^{+2}\right]_{\mathrm{T}}$ $\left([P C C]_{T}=4.0 \times 10^{-4} \mathrm{~mol} \mathrm{dm}^{-3}, t=30^{\circ} \mathrm{C} .\left[\mathrm{Pd}^{+2}\right]\right.$ was varied from $2.83 \times 10^{-3} \mathrm{~mol} \mathrm{dm}^{-3}$ to $14.15 \times 10^{-3} \mathrm{~mol}$ $\mathrm{dm}^{-3},\left[\mathrm{H}^{+}\right]=0.01 \mathrm{~mol} \mathrm{dm}^{-3}$ and $[\mathrm{GSH}]=0.002 \mathrm{~mol} \mathrm{dm}^{-3}$ )

The temperature variation was carried out in the range $20{ }^{0} \mathrm{C}$ to $40{ }^{\circ} \mathrm{C}$. With the increase in temperature, $\mathrm{k}_{\mathrm{obs}}$ was found to increase. With $[\mathrm{GSH}]_{\mathrm{T}}=2 \times 10^{-3} \mathrm{~mol} \mathrm{dm}^{-3}[\mathrm{PCC}]_{\mathrm{T}}=4 \times 10^{-4}$ $\mathrm{mol} \mathrm{dm}{ }^{-3},\left[\mathrm{H}^{+}\right]=0.01 \mathrm{~mol} \mathrm{dm}$ and $\left[\mathrm{Pd}^{+2}\right]=2.83 \times 10^{-5} \mathrm{~mol} \mathrm{dm}{ }^{-3} 10^{4} \mathrm{k}_{\text {obs }}\left(\mathrm{s}^{-1}\right)$ changed from 5.25 to 9.21 as the temperature was changed from $20{ }^{\circ} \mathrm{C}$ to $40{ }^{\circ} \mathrm{C}$ (Table 1 ).

Table 1. Rate constants for the oxidation of GSH by PCC in presence of $\mathrm{Pd}^{+2}$ at different temperature

\begin{tabular}{|c|c|c|c|c|c|c|}
\hline \multirow{3}{*}{$\begin{array}{c}\text { Temp } \\
{ }^{\circ} \mathrm{C}\end{array}$} & \multirow{3}{*}{$\begin{array}{c}10^{3}[\mathrm{GSH}]_{\mathrm{T}} \\
\mathrm{mol} \mathrm{dm}^{-3}\end{array}$} & \multicolumn{5}{|c|}{$10^{4} k_{o b s}, \mathrm{~s}^{-1}$} \\
\hline & & \multicolumn{5}{|c|}{$\left[\mathrm{H}^{+}\right], \mathrm{mol} \mathrm{dm}^{-3}$} \\
\hline & & 0.010 & 0.015 & 0.020 & 0.025 & 0.030 \\
\hline 20 & 2.0 & 5.25 & 7.66 & 10.01 & 12.58 & 15.28 \\
\hline 25 & 2.0 & 6.03 & 8.94 & 11.33 & 13.98 & 16.77 \\
\hline 30 & 2.0 & 7.13 & 9.78 & 12.56 & 15.39 & 18.25 \\
\hline 35 & 2.0 & 8.07 & 10.72 & 13.70 & 16.63 & 20.53 \\
\hline 40 & 2.0 & 9.21 & 12.06 & 15.19 & 18.40 & 22.90 \\
\hline 20 & 3.0 & 6.55 & 9.22 & 12.01 & 15.07 & 18.47 \\
\hline 25 & 3.0 & 7.69 & 10.50 & 13.33 & 16.49 & 19.92 \\
\hline 30 & 3.0 & 8.92 & 11.81 & 14.92 & 18.42 & 21.62 \\
\hline 35 & 3.0 & 9.77 & 12.79 & 16.19 & 19.79 & 23.79 \\
\hline 40 & 3.0 & 10.84 & 14.06 & 17.66 & 21.46 & 25.46 \\
\hline 20 & 4.0 & 7.68 & 10.94 & 14.44 & 17.94 & 20.44 \\
\hline 25 & 4.0 & 8.77 & 12.23 & 15.63 & 19.43 & 23.13 \\
\hline 30 & 4.0 & 10.56 & 14.12 & 17.60 & 21.40 & 25.10 \\
\hline 35 & 4.0 & 11.39 & 15.15 & 18.93 & 22.93 & 27.23 \\
\hline 40 & 4.0 & 12.23 & 15.99 & 19.77 & 23.77 & 28.07 \\
\hline 20 & 5.0 & 8.83 & 12.09 & 15.59 & 19.19 & 22.59 \\
\hline 25 & 5.0 & 10.07 & 13.38 & 17.08 & 20.88 & 24.58 \\
\hline 30 & 5.0 & 11.98 & 15.49 & 19.39 & 23.19 & 26.89 \\
\hline 35 & 5.0 & 12.93 & 16.64 & 20.84 & 25.44 & 29.14 \\
\hline 40 & 5.0 & 14.22 & 18.00 & 22.28 & 26.98 & 30.88 \\
\hline 20 & 6.0 & 9.85 & 13.11 & 16.61 & 20.21 & 23.61 \\
\hline 25 & 6.0 & 11.35 & 15.30 & 19.10 & 23.20 & 27.50 \\
\hline 30 & 6.0 & 13.71 & 17.91 & 22.55 & 26.65 & 30.35 \\
\hline 35 & 6.0 & 14.72 & 18.92 & 23.72 & 28.12 & 32.02 \\
\hline 40 & 6.0 & 15.03 & 19.29 & 23.93 & 28.36 & 33.06 \\
\hline
\end{tabular}




\section{Stoichiometry and characterization of product}

The stoichimetry of the reaction was studied at $30{ }^{\circ} \mathrm{C}$, where $[\mathrm{PCC}]_{\mathrm{T}}$ was kept constant at $4.00 \times 10^{-4} \mathrm{~mol} \mathrm{dm}^{-3}$ and $[\mathrm{GSH}]=6.00 \times 10^{-3} \mathrm{~mol} \mathrm{dm}^{-3}$, the $\left[\mathrm{H}^{+}\right]=0.01 \mathrm{~mol} \mathrm{dm}^{-3}$ and $\left[\mathrm{Pd}^{+2}\right]$ $=2.83 \times 10^{-4} \mathrm{~mol} \mathrm{dm}^{-3}$. From the decrease in $[\mathrm{PCC}]_{\mathrm{T}}$ and $[\mathrm{GSH}]_{\mathrm{T}}$ the stoichiometry of the reaction can be written as

$$
6 \mathrm{GSH}+2 \mathrm{Cr}(\mathrm{VI}) \stackrel{\mathrm{Pd}^{+2}}{\longrightarrow} 2 \mathrm{Cr}(\mathrm{III})+3 \mathrm{GSSG}+6 \mathrm{H}^{+}
$$

Since $\mathrm{p} K_{1}, \mathrm{p} K_{2}, \mathrm{p} K_{3}, \mathrm{p} K_{4}$ of GSH are 2.05, 3.47, 8.63 and 9.52. (Scheme 1), at higher concentration of the acid $0.03 \mathrm{~mol} \mathrm{dm}^{-3}$, the undissociated form of GSH will participate in the electron transfer reaction. The reaction sequence delineated below (Scheme 2) is consistent with the experimental data.

Deprotonation equilibria of GSH<smiles>CC(C(=O)O)[C@@H](N)CCC(=O)N[C@@H](CS)C(=O)NCC(=O)O</smiles><smiles>N[C@@H](CCC(=O)N[C@@H](CS)C(=O)NCC(=O)O)C(=O)O</smiles>

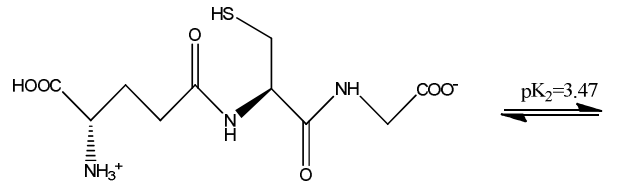<smiles>CC[C@H](NC(=O)CC[C@H](N)C(=O)O)C(=O)NCC(=O)O</smiles><smiles>CC[C@H](NC(=O)CC[C@H](N)C(=O)O)C(=O)NCC(=O)O</smiles><smiles>C1CC[Al]CC1</smiles><smiles>CC[C@H](NC(=O)CC[C@H](N)C(=O)O)C(=O)NCC(=O)O</smiles><smiles>CC(=O)[C@H](N)CCC(=O)N[C@@H](CS)C(=O)NCC(=O)O</smiles><smiles>[C]1CC1</smiles><smiles>C[C@H](NC(=O)CC[C@H](N)C(=O)O)C(=O)NCC(=O)[O-]</smiles>

\section{Scheme 1}

Proposed mechanism for electron transfer<smiles>CCO[Cl+3]([O-])([O-])Cl</smiles><smiles>[C+]=C=C</smiles><smiles></smiles>

C1

$$
\begin{gathered}
\mathrm{GSH}+\mathrm{Pd}^{+2} \stackrel{\mathrm{K}_{2}}{=} \text { Scheme 2 } \\
\mathrm{C}_{1}+\mathrm{C}_{2} \stackrel{k_{1}}{\longrightarrow} \mathrm{Cr}(\mathrm{IV})+\mathrm{GSSG} \\
2 \mathrm{Cr}(\mathrm{IV}) \stackrel{\text { Fast }}{\longrightarrow} 2 \mathrm{Cr}(\mathrm{III})+\mathrm{Cr}(\mathrm{V})
\end{gathered}
$$




$$
\begin{aligned}
& \mathrm{Cr}(\mathrm{V})+\mathrm{GSH} \stackrel{\text { Fast }}{\longrightarrow} \mathrm{GSSG}+\mathrm{Cr}(\mathrm{III}) \\
& \text { Rate }=\mathrm{k}_{1}\left[\mathrm{C}_{1}\right]\left[\mathrm{C}_{2}\right] \\
& =\mathrm{k}_{1} \mathrm{~K}_{1} \mathrm{~K}_{2}\left[\mathrm{H}^{+}\right][\mathrm{PCC}]_{\mathrm{e}}\left[\mathrm{Pd}^{+2}\right]_{\mathrm{e}}[\mathrm{GSH}]_{\mathrm{e}} \\
& {[\mathrm{PCC}]_{\mathrm{e}}=\frac{[\mathrm{PCC}]_{\mathrm{T}}}{1+\mathrm{K}_{1}\left[\mathrm{H}^{+}\right]}} \\
& \text {Rate }=\frac{\mathrm{k}_{1} \mathrm{~K}_{1} \mathrm{~K}_{2}[\mathrm{PCC}]_{\mathrm{T}}\left[\mathrm{H}^{+}\right]_{\mathrm{e}}\left[\mathrm{Pd}^{+2}\right][\mathrm{GSH}]_{\mathrm{e}}}{1+\mathrm{K}_{1}\left[\mathrm{H}^{+}\right]_{\mathrm{e}}} \\
& \text { Rate }=\mathrm{k}_{\mathrm{obs}}[\mathrm{PCC}]_{\mathrm{T}} \\
& \mathrm{k}_{\mathrm{obs}}=\frac{\mathrm{k}_{1} \mathrm{~K}_{1} \mathrm{~K}_{2}[\mathrm{GSH}]_{\mathrm{e}}\left[\mathrm{H}^{+}\right]_{\mathrm{e}}\left[\mathrm{Pd}^{+2}\right]_{\mathrm{e}}}{1+\mathrm{K}_{1}\left[\mathrm{H}^{+}\right]_{\mathrm{e}}} \\
& \frac{\mathrm{k}_{\mathrm{obs}}}{[\mathrm{GSH}]}=\mathrm{k}_{2}=\mathrm{k}_{1} \mathrm{~K}_{1} \mathrm{~K}_{2}\left[\mathrm{Pd}^{+2}\right]_{\mathrm{T}}\left[\mathrm{H}^{+}\right]_{\mathrm{T}}, \mathrm{k}_{2}^{\prime}=\mathrm{k}_{1} \mathrm{~K}_{1} \mathrm{~K}_{2}
\end{aligned}
$$

$\mathrm{k}_{2}$ is the second order constant for the electron transfer reaction.

The plot of $\mathrm{k}_{\mathrm{obs}} /[\mathrm{GSH}]_{\mathrm{T}}$ versus $\left[\mathrm{H}^{+}\right]_{\mathrm{T}}$ are found to be linear for every $[\mathrm{GSH}]_{\mathrm{T}}$ (Figure 6). From the plot the slope is found to be $\mathrm{k}_{1} \mathrm{~K}_{1} \mathrm{~K}_{2}\left(\mathrm{Pd}^{+2}\right)$. If $\mathrm{k}_{1} \mathrm{~K}_{1} \mathrm{~K}_{2}$ taken as $\mathrm{k}_{2}^{\prime}$, then value of $\mathrm{k}_{2}^{\prime}$ can be stated as $\left\{\right.$ Slope $\left./\left(\mathrm{Pd}^{+2}\right)\right\}$.

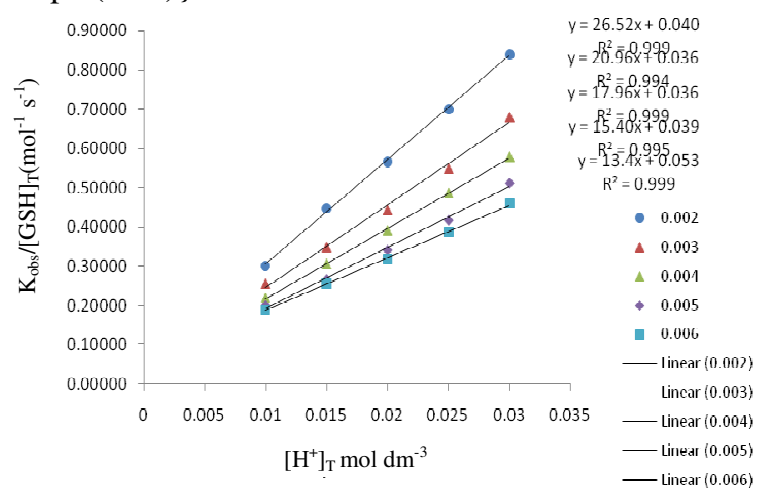

Figure 6. The plots of $\left\{\mathrm{K}_{\mathrm{obs}} /[\mathrm{GSH}]_{\mathrm{T}}\right\}$ versus $\left[\mathrm{H}^{+}\right]_{\mathrm{T}}$ mol dm ${ }^{-3}$ at different $[\mathrm{GSH}]_{\mathrm{T}}$ $\left([P C C]_{T}=4.0 \times 10^{-4} \mathrm{~mol} \mathrm{dm}^{-3}, t=25^{\circ} \mathrm{C} .\left[\mathrm{H}^{+}\right]\right.$was varied from .001 to $.003 \mathrm{~mol} \mathrm{dm^{-3 }}$ and $[\mathrm{GSH}]$ was varied from 0.002 to $0.006 \mathrm{~mol} \mathrm{dm}^{-3}$ )

Now by plotting a graph between $\mathrm{k}_{2}^{\prime} / \mathrm{T}$ versus $\mathrm{T}^{-1}$ (Figure 7), a new slope and intercept is obtained. $\Delta \mathrm{H}^{\ddagger}\left(\mathrm{kJmol}^{-1}\right)$ and $\Delta \mathrm{S}^{\neq}\left(\mathrm{JK}^{-1} \mathrm{~mol}^{-1}\right)$ were calculate from the Eyring plot of $\left(\mathrm{k}_{2}^{\prime} / \mathrm{T}\right)$ versus $\left(\mathrm{T}^{-1}\right)$ and were found to be $-27.7 \mathrm{kJmol}^{-1}$ and $-243.9 \mathrm{JK}^{-1} \mathrm{~mol}^{-1}$. The negative values of activation parameters favour the formation of the ordered transition state.

\section{Characterization of product}

The FT IR spectra of GSH (Figure 8 \& 9) and the product were recorded with a Pekin Elmer (U.K) FT IR spectrophotometer. A broad peak at $3419 \mathrm{~cm}^{-1}$ in the product may be assigned to $v_{N-H}\left(\mathrm{NH}_{3}^{+}\right)$, as compared to $3252 \mathrm{~cm}^{-1}$ and $3026 \mathrm{~cm}^{-1}$ in GSH. The shifting to higher frequency is probably due to an association of water molecules with the product. The $\mathrm{NH}_{3}{ }^{+}$ bending bands and a strong absorption peak of carboxylate ion are mixed up and a broad band 
is observed at $1636 \mathrm{~cm}^{-1}$ in the product compared to $1600 \mathrm{~cm}^{-1}, 1538 \mathrm{~cm}^{-1}$ and $1395 \mathrm{~cm}^{-1}$ peaks in GSH. The weak band at $2526 \mathrm{~cm}^{-1}$ in GSH due to S-H stretching is absent in the product (Figure 8) suggesting the dimerization of GSH having S-S linkage. Strong and broad peak of $1089 \mathrm{~cm}^{-1}$ and a sharp peak of $628 \mathrm{~cm}^{-1}$ in the product corresponds to $1073 \mathrm{~cm}^{-1}$ and $691 \mathrm{~cm}^{-1}$ in GSH is due to the free $\mathrm{NH}_{2}$ twisting \& rocking ${ }^{18}$.

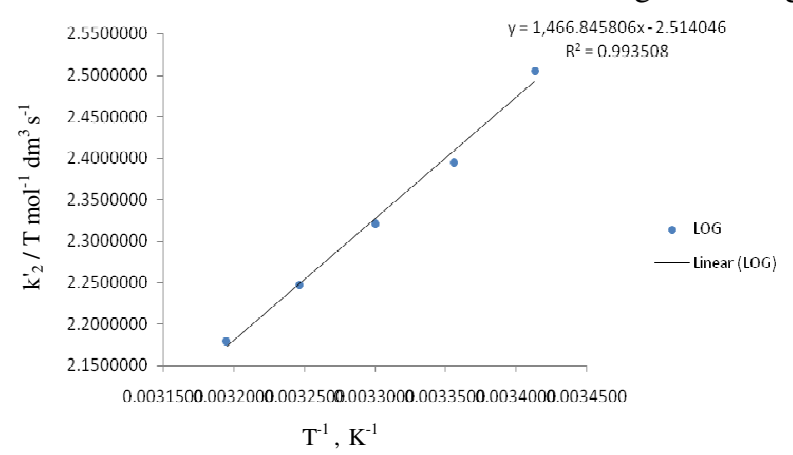

Figure 7. The plots of plot of $\mathrm{k}_{2}^{\prime} / \mathrm{T}$ versus $\left[\mathrm{T}^{-1}\right]$

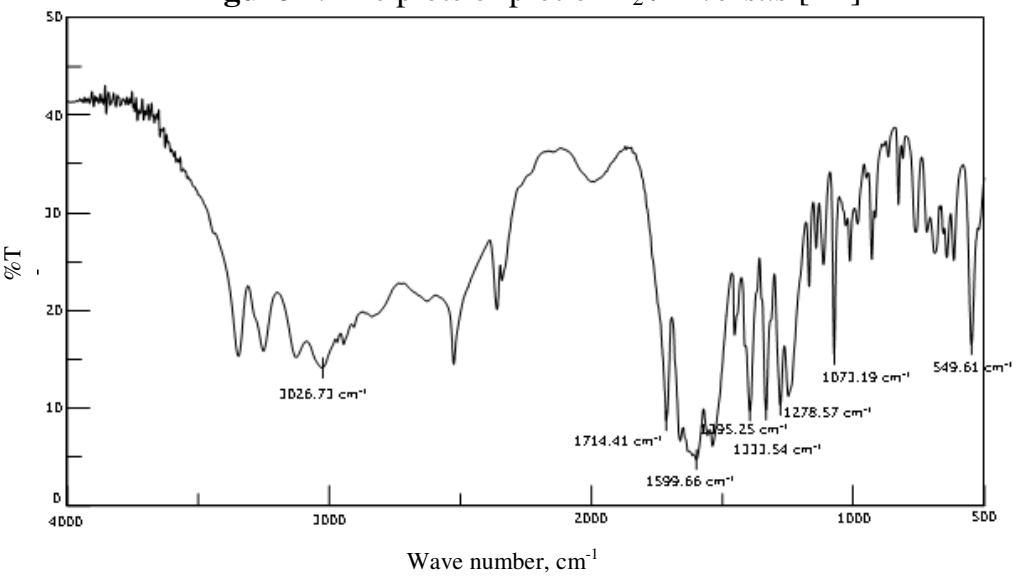

Figure 8. IR spectra of pure GSH

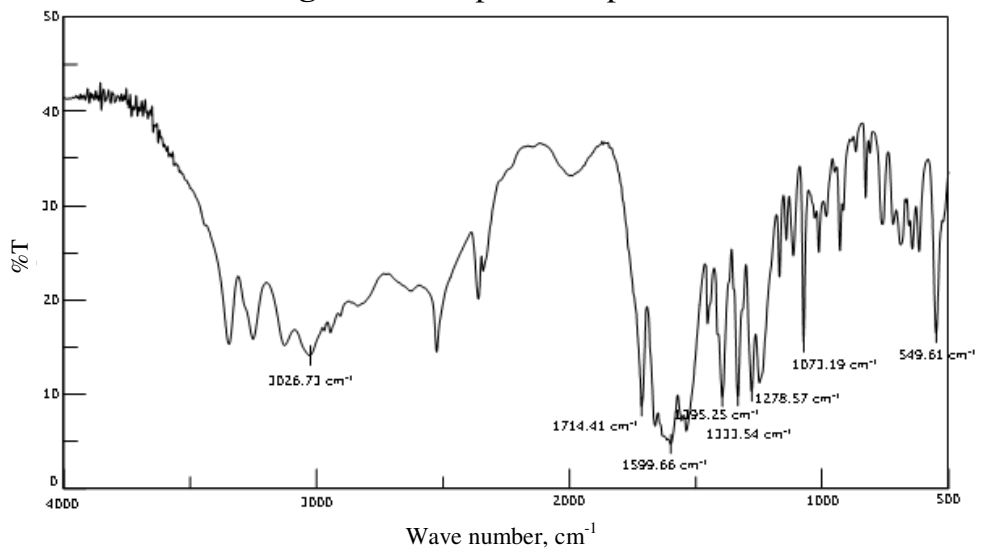

Figure 9. IR spectra of the product 


\section{References}

1. Jain S, Hiran B L and Bhatt C V, J Chem., 2009, 6(1), 237-246.

2. Hunsen M O, Tetrahedron Lett., 2005, 46(10), 1651-1653.

3. Hiran B L, Meena M L and Kunthwal J, Der Pharma Chemica, 2010, 2(5), 470-478.

4. Luzzio F A, Fitch R W, Moore W J and Mudd K J, J Chem Edu., 1999, 76(7), 974.

5. Rajasekaran K, Baskaran T and Gnanasekaran C, J Chem Soc., Perkin Trans 2, 1984, 1183-1186.

6. Ramana Rao V V, Devaprabhakara D, Chandrasekaran S, J Organometallic Chem., 1978, 162(1), C9-C10. ISSN 0022-328X.

7. Palaniappan S and Amarnath C A, Polym Adv Technol., 2003, 14(2), 122-128.

8. Beihoffer L A, Craven R A, Knight K S, Sisson C R and Waddell T G, Trans Metal Chem., 2005, 30(4), 582-585.

9. Hunsen M O, Synthesis, 2005, 2487-2490.

10. Cha J S and Chun J H, Bull Korean Chem Soc., 2000, 21(4), 375.

11. Sharma V, Sharma P K and Banerji K K, J Indian Chem Soc., 1997, 74, 607-609.

12. Dixon D A, Dasgupta T P and Sadler N P, J Chem Soc Dalton Trans., 1995, 2267-2271.

13. Hiran B L, Dulawat S S, Rathod R and Rathod N, J Chem., 2007, 4(2), 279-283.

14. Wang Steven S S, Hung Ying-Tz and Lin Yu-Chi, Bioprocess Biosystems Engineering, 2010, 33, 277-286.

15. Mishra K K and Chaturvedi R, Progress in Reaction Kinetics and Mechanism, 2008, 33(3), 253-265.

16. Corey E J and Suggs W J, Tetrahedron lett., 1975, 16(31), 2647-2650.

17. Jeffery G H, Bassett J, Mendham J and Denney R C, Vogel's Text Book of Quantitative Chemical Analysis, $5^{\text {th }}$ Edition, ELBS with Longman, 1989, Chapter 11, Cluse no 11.36, 463.

18. Nakamoto K, Infrared and Raman Spectra of Inorg and Coord Compexes, $5^{\text {th }}$ Edn. John Willey and Sons Inc., Publication, 1997. 